\title{
THE CONCEPT OF LAND PLOT AS A COMBINATION OF SMART CONTRACTS: A VISION FOR CREATING BLOCKCHAIN CADASTRE
}

\author{
Andrii Martyn \\ National University of Life and Environmental Sciences of Ukraine
}

\begin{abstract}
The key features of the blockchain databases, such as decentralization, distribution, security, and record of the history of all transactions, create significant prospects for their application in the field of cadastre and real estate registration activities, including creation of the global real estate cadastre infrastructure, which will be able to go beyond national legal systems and jurisdictions. The conceptual approach to registration of land plots as spatial objects using blockchain technology is proposed. The land plot should be considered as a combination of smart contracts between landowners, surveyors, appraisers, notaries and other persons. The subject of such contracts will be the description and establishment of spatial (plot boundaries, territorial zones, etc.) and other (property rights and encumbrances, monetary valuation, soil bonitet, etc.) characteristics of land plots. The classification of such smart contracts reliability is also presented.

Key words: land cadastre, land plot, blockchain, smart contract, global cadastre.
\end{abstract}

\section{Introduction}

In recent years, it becomes clear that the blockchain technology may have a much wider application than the crypto-currency market. Key features of databases based on blockchain technology, in particular: shared databases, multiple writers, distributed trust, disintermediation, transaction dependency, timestamping, transaction rules, validation, scalability etc., cause significant prospects for their application in the field of cadastral and property registration activities. In particular, today it is possible to model scenarios, in which the state will no longer perform the function of a guarantor of rights to real estate, as well as establish technical and organizational grounds for launching a global cadastral system, which will go beyond national legal systems and jurisdictions. At the same time, many researchers pay attention to the multiple risks related with the transition to blockchain technology implementation in land registration.

Study conducted by the European University Institute (EUI) and European Private Law Forum (2005) indicates that various systems of real estate registration in Europe often are divided between five basic "legal families": Common Law; Civil Law of the countries of the Napoleonic Code; Civil Law of Germany (or of Central Europe); Civil Law of the former Communist countries; Law in the Scandinavian countries. Lodde (2016) conclude, that distinguishing factors between the five families listed above are numerous, but there are five that most readily facilitate the comparison: the organization of the registry; the content of the registration; the substantial effects of registration; the protection (or non-protection) of good faith; the effects toward third parties. In most of the European systems, the structure of the "property sheet" is made up of three parts: (1) description of the property, usually identified with a unique number; (2) ownership of the property; (3) the rights of others on the property, burdens and mortgages.

Real property registration systems of developed countries, as a rule, remain quite traditional and sensitive to changes. At the same time, their "immutability", perhaps, should be regarded as one of the conditions for public trust in their services over the centuries. It should be noted that none of the European countries has fully implemented the registration of real property rights for real estate on the technology of distributed databases.

The concept of a land registry built on the blockchain technology basis is particularly attractive for developing countries or countries conducting land reforms, where cadastral systems are not conservative or at the stage of technological and information development. The state cannot always be considered a reliable guarantor of real estate rights, since officials are often prone to traditional "paper" registration technologies, there is always the possibility of losing the registration data due to negligence, emergency situations, war, etc. Unfair government officials and registrars for whom 
registration procedures create a broad field of corruption are becoming a problem for poor countries. Often, at the stage of registering real property rights, the state is trying to interfere in market transactions and limit the economic freedoms of entrepreneurs and citizens.

For example, in Ukraine, where the cadastral system is still in development, the government's decision in 2016 to introduce blockchain technology in the State Land Cadastre has generated considerable enthusiasm in society and the professional environment. In conditions, when paper documents on real estate registration in parts of the country (Crimea, Sevastopol, certain areas of Donetsk and Lugansk regions) are lost or inaccessible due to military occupation, the transfer of the cadastral system to technology, which can guarantee the storage of records of property rights to land and other real estate in a distributed database seems to be a rather tempting idea. Unfortunately, the actual implementation of the blockchain cadastre in Ukraine did not go further than specifying a hash-tag in the cadastre certificates, which could be used only for verifying the validity of the document, while the land cadastre database itself is still kept in traditional form and has not become distributed.

Vos, Lemmen and Beentjes (2017) point out, that compared with a 'classic land registration system', blockchain may even provide some additional certainty. Because of the shared databases there is security of back-ups. Trust is added by cryptographic proof and a decentralized database, especially in the case the current administrator (registrar) is not trusted. It might save costs because of remediation of intermediaries (notaries or licensed conveyancers) or administrators (registrars). Therefore, it can be judged as an alternative for the classical land registers. But without the cooperation of legal and geodetic professionals, who indicate the legal and geodetic meaning and its implications, the use of blockchain might not be applicable in the right way and might even backfire in the absence of knowledgeable (legal and geodetic) council. Implementation of such techniques could result in unforeseen circumstances.

Barbieri et.al. (2017) conclude that in judicial matters blockchain raises serious security concerns, promotes tax fraud and money laundering and itself does not offer any solutions for document and data storage, data transport and data protection, issue of certificates and the transfer of ownership to users, genuine authentication of users, preservation of evidence and encryption, protection against key loss and sustainable management. So, from today's perspective, blockchain technology seems to be useful only in the context of machine-to-machine communication, because of the high affinity of the blockchain for standards: the more participants and transaction types exist, the more complex the adoption of new standards becomes.

Peiró and Martinez García (2017) considering the legal aspects of the use of blockchain in land registers, note that the transfer of land rights is not similar to the transfer of shares, since the rights to land are more complex.

It should be noted that the existing studies are largely focused on the use of blockchain technology, first of all, when registering property rights (titles) for land plots. However, many researchers note that the role of a surveyor, who is responsible for describing the spatial characteristics of real estate, as well as the role of a registrar or a notary, certifying the legality of the transaction, does not find sufficient reflection in the concept of the blockchain land registry.

Thus, the conceptual approaches to blockchain registration of land parcels as spatial objects, in the formation of which not only landowners or land users take part, but also land surveyors, appraisers and other specialists carrying out a description of spatial and other characteristics of land plots, remain practically unexplored.

\section{Methodology of research and materials}

The purpose of the study was to define a conceptual approach to describing the characteristics of a land plot when maintaining a land registry using the blockchain technology. Technical aspects of blockchain land registry were not considered, but the article operates with the generally accepted concept of this technology as continuously growing list of records, called blocks, which are linked and secured using cryptography. Each block typically contains a cryptographic hash of the previous block, a timestamp, and transaction data. The concept of a smart contract in this article is taken as a computer protocol intended to digitally facilitate, verify, or enforce the negotiation or performance of a contract. Smart contracts allow the performance of credible transactions without third parties. These 
transactions are trackable and irreversible. In the course of the research, an attempt was made to introduce the new concept of the "land plot" as a set of smart contracts, at the conclusion of which a fixation of various characteristics of the real property is made.

It should also be noted that the registration system based on blockchain technology can in fact be considered as a further extension of the type of land registration systems based on the registration of deeds (documents), since the system will register transactions (contracts) regarding land plot.

\section{Discussions and results}

It is worth noting that the use of blockchain technology for the registration of real estate will require, first of all, an introduction of a new definition of the concept of "land plot" as a set of smart contracts, the subject of which is the establishment of spatial (boundaries of land, restrictions, lands, servitudes, etc.) and others (monetary value, soil yield class, market value, etc.) characteristics of land plots. Smart contract (hereinafter - SC) is a computer protocol that simplifies, verifies, ensures compliance with the negotiation or execution of the contract. Signatories (parties) of such SC should be: (1) owners (users) of land plots; (2) owners (users) of adjacent land plots; (3) competent engineers carrying out a geodetic description of the boundaries (surveyors); (4) competent specialists who establish other characteristics of the land plot (for example, notaries, appraisers, soil scientists, hydrologists, geologists, etc.) (Fig. 1).

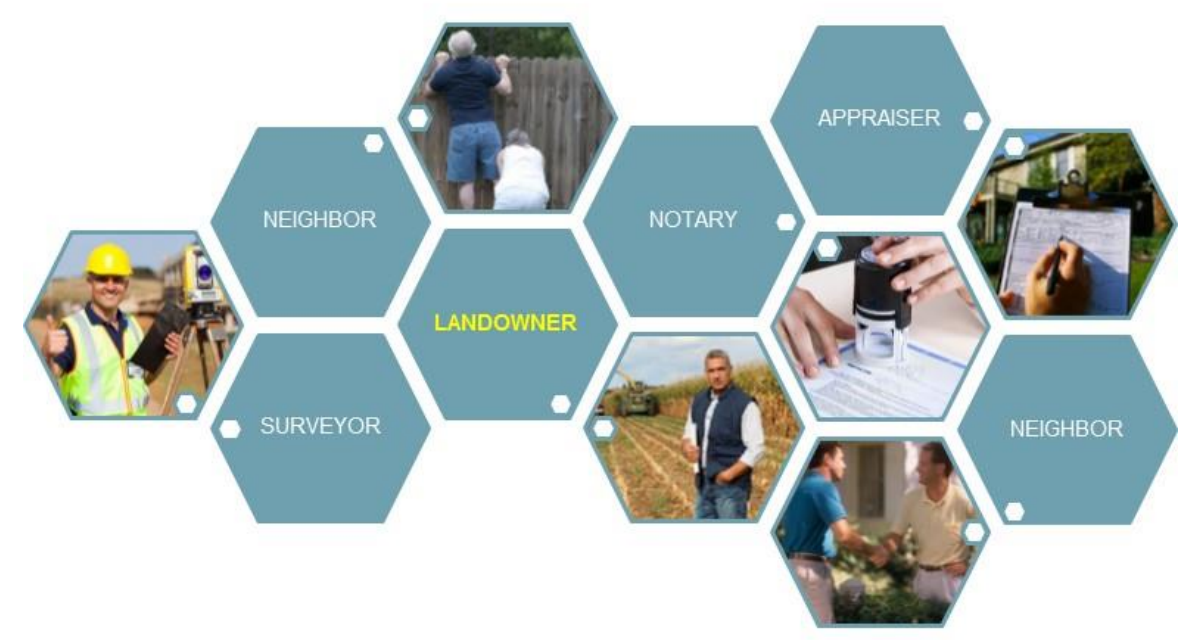

Fig. 1. The conceptual model of interaction of participants of the land plot related smart contracts.

In an ideal situation, the boundary of a land plot should be considered as the result of a multilateral SC, which outlines a standardized geodetic description of the boundary between the land plot and neighboring plots signed by the electronic digital signature of the land surveyor and the signatures of the landowner and owners of adjacent land plots. Taking into account that consensus on all spatial characteristics of a land plot may take a long time, spatial characteristics of land plots should be recorded using SC with different levels of reliability - from the most primitive to the most perfect ones.

A separate issue will also be the procedure for the initial recognition of land plot ownership. Obviously, at the initial stage of the functioning of the new registration system, this function can be assigned to a group of special persons - notaries or state registrars who will nominally sign the first ("zero") SC, confirming the existence of rights of owner to the land plot, based on existing title documents at the time of the first registration in the blockchain database.

Five different levels of reliability of the SC related with registration of the land plots and their properties can be offered. Information on land plots registered with SCs with a higher level of reliability, respectively, should have priority in the event of conflicts or disputes. 
Level I: Description of the boundaries of the land plot is absent

In fact, contract should be considered "zero" SC, if it is concluded between the owner and the person who certifies with his signature the primary registration of the existing right (notary or registrar). The basis for the primary registration of the right should be the title documents available to the owner, on the basis of which his rights are confirmed. Thus, the "zero" contract serves, first of all, for the confirmation of the title to the land plot. This contract, in addition to ascertaining the existence of the right to a real estate object, may also provide a payment of the services of a person confirming ownership.

Level II: Description of the boundaries of the land plot is absent, but location of the land plot is described as a point object

$\mathrm{SC}$ is signed between the owner of the land plot by the land surveyor who described the geographical location of the land plot with the coordinates of its centroid. This type of SC may provide payment for the services of the land surveyor. Such a way of identifying the location of land plots can be considered as one of the most primitive, but for countries with low incomes, even such a simple spatial identification of a land plot can be a mass solution for the initial filling of land registry data.

Geographical identification of the land plot can be specified later by signing new SCs with the land surveyor, on the basis of which a new block with updated information about the coordinates of the centroid of the land plot will be added to the blockchain.

Land plots registered with a second level of reliability on the coordinates of the centroid will in fact correspond to the concept of a "point cadastre" (Antwi et.al., 2012).

Level III: Boundary of land plots is described as a line(s)

In this case, the subject of the SC is the establishment of a boundary between two neighboring land plots. The boundary is described in the form of a polyline(s) with known coordinates of the turning points, as well as an indication of the accuracy with which they were determined. In this case, the subject of the SC is the establishment of a boundary between two neighboring land plots. The boundary is described in the form of a polyline with known coordinates of the turning points, as well as an indication of the accuracy with which they were determined. The contract is signed by the land surveyor, who established the border, as well as the owner of the land plot.

In fact, in this case the border can be established "unilaterally". Of course, the land surveyor, within the limits of his competence, must identify the existing boundaries of the land plot on the terrain, if such boundaries are fixed by landmarks. At the same time, the existence of land plots, boundaries of which are not identified on the ground is quite possible (for example, plots allocated as land shares in the process of land reform within the boundaries of the field).

Level IV: Boundary of the land plot is described as the line agreed by the neighboring landowners

In this case, the boundary between two land plots is established by the land surveyor as a polyline in a manner similar to the third level of reliability. But the main feature of a SC is now multilateralism: it must be signed by the land surveyor, who established the border, and both adjacent landowners, whose land plots share this border.

It can be noted, that in this case the contract will in fact perform the function of coordinating the border between neighbors. Of course, further changes to the boundary established in this way can occur solely by mutual agreement of the owners of adjacent land plots.

A prerequisite for such a delimitation is also the presence of registered property rights for the neighbor's plot. A block with geographic information about an agreed by SC boundary line between parcels should be added to the blockchain on both land plots.

Level V: The boundary of the land plot is described as a polygon

This level of reliability of registration, in fact, is not connected with the signing of additional SCs, but it reflects the state of registration of the land plot, under which contracts corresponding to the fourth level of reliability are concluded with all owners of adjacent land plots. Thus, the set of polylines of individual boundaries conditionally turns into a closed polygon.

The SC may also envisage the entry into force after verification of the spatial (geodetic) parameters of the land plot by another land surveyor or group of land surveyors, which may be considered as an additional way to increase confidence in the information to be recorded. 
When transferring rights to a land plot, its spatial characteristics, recognized by the previous owner, will be preserved, and their change will require the conclusion of appropriate new SCs. Fixing other characteristics of a land plot (for example, a monetary valuation of a plot, boundaries of land, soil cover, etc.) should be considered as the subject of landowner's SCs with competent specialists, which provide relevant data.

One of the traditional functions of land registers is the guarantee of property rights and the resolution of disputes, which requires, first of all, retrospective information on all actions that took place with rights to the land plot and its borders. Taking into account the distribution and publicity of the land registry, the management of which is carried out on the basis of the detachment, it can perform such a function quite effectively.

An interesting option arising from the development of a distributed land registry on the basis of a blockchain is the possibility of creating a global cadastre that will no longer depend on national legislation and jurisdictions. Sooner or later, before mankind there will be a need to register real rights to immovable property (or objects equated to immovable property) located beyond the surface of the Earth and state borders, and for this purpose the blockchain property registry will be very convenient. Undoubtedly, this is a very distant prospect, but this is not an excuse for the scientific community to postpone consideration of these possibilities.

It should also be noted that the registration system based on blockchain technology can be viewed as a further continuation of the type of land registration systems based on the registration of deeds (documents), since the system will actually register transactions that are subject to rights to the land plot or its characteristics.

The development of distributed land registers can take place both with the support of the state (when it considers the blockchain-cadastre as a way to reduce government costs) and when it counteracts (when the state does not want to lose monopoly control over the registration of property rights). In the second case, an interesting option may be the creation of special organizations or companies that will perform the function of a nominal owner of real estate in accordance with the national legislation of the country in which it is located. In turn, the actual right to own or use land plots can be provided on the basis of the registration data provided by the "non-state" distributed land registry.

\section{Conclusions and proposals}

The creation of distributed land registries (cadasters) based on blockchain technology still raises concerns among many experts in the field of law, land administration and cadastral systems. At the same time, the possibilities of this technology inspire many researchers to find new ways of reliable registration of property rights for real estate.

The key idea of this research is to consider the land plot as a set of "smart contracts" between the landowner and land surveyors, notaries, appraisers and other specialists whose work creates an array of information about the land parcel as a real estate object.

The proposed approach can be considered as one of the first attempts to define a concept on the basis of which it is possible to develop a decentralized blockchain infrastructure not only for registration of transactions with real estate, but also spatial and other characteristics of real estate as objects of property rights. In the long run, this will allow governments to deprive not only the functions of the registrar of real rights to real estate, but also the functions of administering the cadastre of real estate, reducing the taxpayers costs.

Further studies may be devoted to the development of unified formats for describing information on land plots within the framework of a distributed land registry. Also, the technical feasibility of effective operation of such registries should be assessed based on the volume of the database, the number of transactions conducted, and the quality of the cadastral data. Further research is also needed to improve the means of identifying the owner of real estate, prevent fraud, and control the accuracy of geospatial data.

\section{References}

1. Real Property Law and procedures in the European Union - General Report, 31/5/2005. Study conducted by the European University Institute (EUI) Florence / European Private Law - www.iue.it - Forum Deutsches Notarinstitut (DNotI) Würzburg. 
2. Lodde A. (2016). The European systems of real estate. Territorio Italia. 2016;2016(1/16):23-42 DOI 10.14609/Ti_1_16_2e

3. Vos J., Lemmen C.H.J., Beentjes B. (2017). Blockchain-based Land Administration: Feasible, Illusory or Panacae? In Responsible Land Governance: Towards and Evidence Based Approach, Washington, D.C. March 20-24, 2017 : Proceedings of the Annual World Bank Conference on Land and Poverty Washington, D.C.: The World Bank.

4. Barbieri, M., Gassen, D. (2017). Blockchain - can this new technology really revolutionize the land registry system? Paper prepared for presentation at the " 2017 World Bank Conference on Land and Poverty" The World Bank - Washington DC, March 20-24, 2017. Viewed 7 June, 2018, (http://www.notartel.it/export/contenuti_notartel/pdf/Land_Poverty_Conference_Blockchain.pdf).

5. Peiró N., Martinez García E. (2017). Blockchain and Land Registration Systems. European Property Law Journal, 6(3), pp. 296-320.

6. Antwi R., Bennett R., De Vries W., Lemmen C., Meijer C. (2012). Requirements for point cadastres. In: FIG Working Week 2012, Rome, 6-10 May 2012 "Knowing to manage the territory, protect the environment, evaluate the cultural heritage. Rome: FIG. 2012, 11 p.

7. Hackman-Antwi R., Bennett R., De Vries W., Lemmen C., Meijer C. (2013) The point cadastre requirement revisited, Survey Review, 45:331, 239-247, DOI: 10.1179/1752270612Y.0000000015

8. McDougal, K \& Bennett, Rohan \& van der Molen, Paul. (2013). The global cadastre. 27. 30-34.

9. Loenen, Bastiaan van, Sergio NassarreAznar, Hendrik Ploeger, 2005, EuroTitle: a standard for European Land Registry Paving the road to a common real estate market. GIM International Volume 18, ISSN 1566 9076.

\section{Information about author}

Andrii Martyn, Dr.Hab. in Economics, Assoc. Prof., Head of the Land-Use Planning Department, National University of Life and Environmental Sciences of Ukraine. Address: Office 117, 17 Valylkivska str., Kyiv, 03040, Ukraine; phone: +380672745061; e-mail: martyn@nubip.edu.ua . Fields of interest: land administration, spatial planning, land market regulation, cadastre systems. 